\title{
Double plating technique for fixing tibial plateau leveling osteotomy and modified cranial closing wedge ostectomy of the tibia in a dog with cranial cruciate ligament disease and excessive plateau angle: case report
}

\author{
[Técnica de placa dupla para fixação concomitante da osteotomia de nivelamento do platô tibial e \\ ostectomia modificada em cunha de fechamento cranial da tíbia em um cão com doença do \\ ligamento cruzado cranial e ângulo de platô tibial excessivo: relato de caso] \\ B.W. Minto ${ }^{1}$, C.R.G.P. Lopes $^{2}$, P.P. Rossignoli ${ }^{3}$, G.G. Franco ${ }^{3}$. \\ F.Y.K. Kawamoto ${ }^{3}$, A.G. Sprada ${ }^{3}$, L.G.G.G. Dias ${ }^{1}$ \\ ${ }^{1}$ Universidade Estadual Paulista (Unesp) - Jaboticabal, SP \\ ${ }^{2}$ Aluno de graduação - Universidade Estadual Paulista (Unesp) - Jaboticabal, SP \\ ${ }^{3}$ Aluno de pós-graduação - Universidade Estadual Paulista (Unesp) - Jaboticabal, SP
}

\begin{abstract}
Tibial plateau leveling osteotomy (TPLO) associated to cranial wedge closing ostectomy (CCWO) has been one of the best options to manage cranial cruciate ligament (CCL) disease and excessive tibial plateau angle (TPA) in large dogs, however, the complication rate is potentially high. It is believed that a more robust fixation is necessary to stabilize them and decrease the risk of implant failure. A 6-year-old male American Pit Bull, weighing 36kg, with 90-day history of right hind limb lameness, was diagnosed with CCL disease. Due to the excessive tibial plateau angle $\left(42^{\circ}\right)$, TPLO was associated with a modified CCWO using a double plating technique. A final TPA of $12^{\circ}$ was accomplished, and a restricted level of exercises and physiotherapy were recommended. The patient was followed monthly until the fifth month postoperatively, when radiographic bone consolidation and no lameness were observed. By the date of this submission, 3 years after the procedure, the owner has reported no complications. The double plating technique for fixing TPLO and modified CCWO proved to be effective for the treatment of CrCL deficiency in a large dog with an excessive TPA.
\end{abstract}

Keywords: dogs, CCWO, orthopedics, TPA, TPLO

\section{RESUMO}

A osteotomia de nivelamento do platô tibial (TPLO) associada à ostectomia modificada em cunha de fechamento cranial da tíbia (CCWO) tem sido uma das melhores opções para tratamento de cães grandes com doença do ligamento cruzado cranial (DLCCr) e ângulo excessivo do platô tibial, mas o índice de complicações é alto. Acredita-se haver necessidade de fixação mais robusta para reduzir as chances de falha nos implantes. Um cão macho, seis anos, da raça American Pit Bull, 36kg, com histórico de claudicação em membro pélvico direito há 90 dias, foi diagnosticado com DLCCr. Devido ao ângulo excessivo do platô tibial $(42$ ), a osteotomia de nivelamento do platô tibial foi associada à ostectomia modificada em cunha de fechamento cranial da tíbia $(C C W O)$ por meio da técnica de placa dupla. No pósoperatório imediato, identificou-se TPA de $12^{\circ}$; exercícios controlados e fisioterapia foram recomendados e a evolução do quadro foi analisada mensalmente até o quinto mês pós-cirurgia. Com 150 dias de evolução, não houve alterações de locomoção e havia ocorrido completa consolidação radiográfica das osteotomias. Até o momento da submissão deste artigo, três anos pós-procedimento, o tutor relata ausência de complicações, via contato telefônico. Portanto, a técnica modificada mostrou-se eficaz no tratamento da DLCCr.

Palavras-chave: cães, CCWO, ortopedia, TPA, TPLO

Recebido em 24 de agosto de 2020

Aceito em 18 de dezembro de 2020

E-mail: bruno.minto@unesp.br 


\section{INTRODUCTION}

Cranial cruciate ligament (CCL) disease is one of the most common causes of hind limb lameness in dogs and it leads, potentially, to progressive osteoarthritis of the stifle joint (Powers et al., 2005). Although its etiopathogenesis has not been fully elucidated so far, it is likely multifactorial, and considered to be a degenerative process, commonly affecting both pelvic limbs. Some risk factors may be associated with the disease such as breed, excessive tibial plateau angle, obesity and sedentary lifestyle (Kowaleski et al., 2012; Bergh et al., 2014). Several surgical techniques have been described for the treatment of CCL disease and, among them, TPLO seems to be superior to others (Bergh et al., 2014; Livet et al., 2019).

The level of inclination of the tibial plateau (TPA) can be considered a primary developmental or congenital abnormality that may lead to partial rupture of cranial cruciate ligament and, the more inclined it is the more likely for the cranial cruciate ligament to be overloaded (Morris and Lipowitz, 2001). Some dogs are considered to have an excessive TPA when it is greater than $34^{\circ}$ (Talaat et al., 2006). In these cases, TPLO requires large proximal tibial fragment rotation, increasing, substantially, the risk for fractures and insufficient rotation (Talaat et al., 2006; Duerr et al., 2008).

A combination of TPLO and cranial closing wedge ostectomy (CCWO) has been reported for the treatment of patients presenting TPA greater than $36^{\circ}$, however, complication rates can reach $78 \%$ (Talaat et al., 2006). Pin migration, seroma, implant failure, patellar tendon thickening, pain on surgical site and abnormal ambulation have been observed (Talaat et al., 2006; Duerr et al., 2008; Weh et al., 2011). We hypothesized that using a more robust fixation, the risk for implant failure would be lower. In view of how challenging combining TPLO and CCWO would be and its potential for postoperative complications, the aim of this paper was to report the case of a dog with excessive tibial plateau angle and cruciate ligament disease treated with TPLO and CCWO using a double plating technique.

\section{CASUISTRY}

A six-year-old male American pit bull, weighing $36 \mathrm{~kg}$, was presented for ninety-day history of right hind limb lameness. The lameness had a sudden onset, and no trauma was observed by the owner, although they reported that the patient had a traumatic fracture on the same limb five years prior. The previous patient's radiographic file showed an avulsion of the tibial tuberosity and a salter Harris type I fracture occurred five years before. According to the owner, only conservative treatment with bandage and resting was performed with full recovery of the limb function. Orthopedic exam revealed right stifle crepitus, positive drawer test and cranial tibial thrust test, suggesting cranial cruciate ligament insufficiency. Complete blood count and biochemical tests (creatinine and alanine aminotransferase) showed normal parameters. Radiographs revealed a wide difference in the tibial plateau angle (TPA) between right $\left(42^{\circ}\right)$ and left stifles $\left(23^{\circ}\right)$, probably due to the malunion caused by the conservative fracture management previously described (Figure 1). The association of TPLO and modified CCWO was chosen for managing it.

The dog was pre-medicated with acepromazine (Acepran, acepromazine, Vetnil, Brazil) $(0.05 \mathrm{mg} / \mathrm{kg} \mathrm{IM})$ and meperidine (Meperidina, meperidina, União Química, Brazil) (4mg/kg IM). The induction was performed with propofol (Provive, propofol, União Química, Brazil) $(5 \mathrm{mg} / \mathrm{kg}$ IV) and maintained with isoflurane (Isoflurano, isoflurane, Biochimico, Brazil) diluted in $100 \%$ oxygen. Additionally, an epidural anesthesia was performed with $2 \%$ lidocaine (Lidovet, lidocaine, Bravet, Brazil) without a vasoconstrictor $(5 \mathrm{mg} / \mathrm{kg})$ and morphine (Morphine, morphine, Cristália, Brazil) $(0.1 \mathrm{mg} / \mathrm{kg})$. Surgical planning followed the guidelines proposed by Talaat et al. (2006). The aim was to reach a postoperative TPA of $5^{\circ}$. According to the planning, the angular reduction provided by CCWO would be $15^{\circ}$. Therefore, the TPLO technique was based on a new TPA, which would be $27^{\circ}$ and not the original one $\left(42^{\circ}\right)$. TPLO blade was defined using templates and lateral radiography. The size of the wedge was defined by the equation $\tan \theta=Y / X$, where $x$ is the distance from the caudal margin of TPLO to the cranial region of the tibia (Figure 2). 


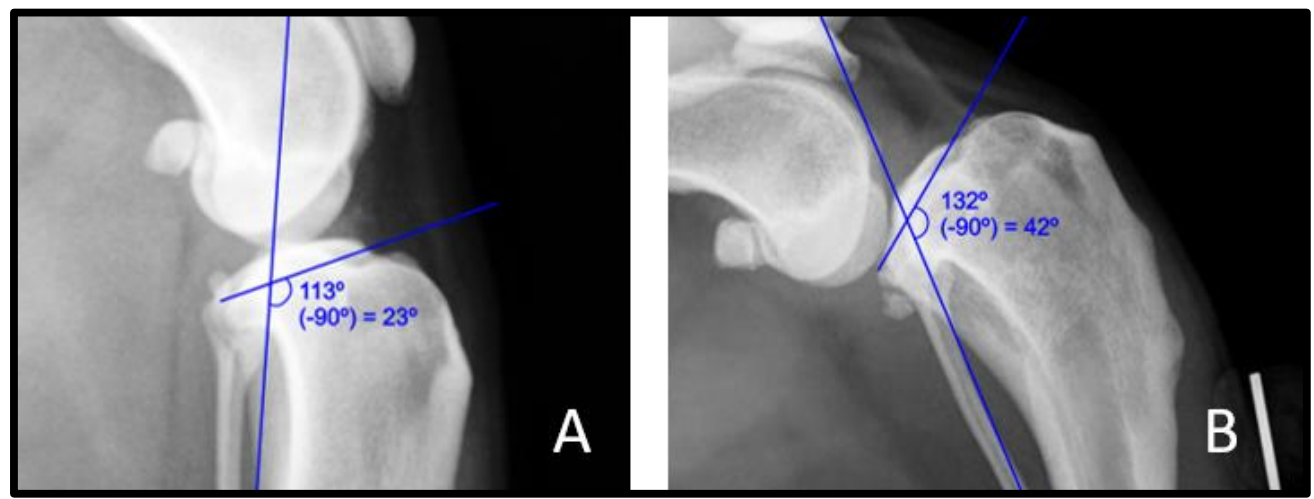

Figure 1. Lateral radiographs of a male American pit bull dog showing tibial plateau angle measurement of both stifle joints for surgical planning of the association of TPLO and modified CCWO A. Left stifle joint presenting TPA of $23^{\circ} \mathrm{B}$. Right stifle joint presenting TPA of $42^{\circ}$.

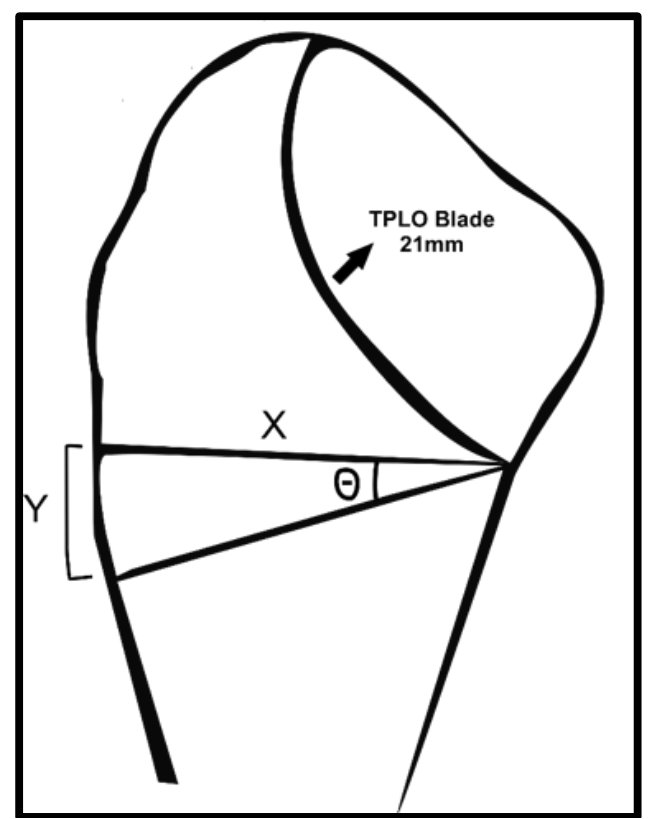

Figure 2. Illustrative picture demonstrating the surgical planning to perform CCWO and TPLO osteotomies in an American pit bull male dog. The size of the wedge was defined by the equation $\tan \Theta=\mathrm{Y} / \mathrm{X}$, where $x$ is the distance from the caudal margin of TPLO to the cranial region of the tibia.

After the medial approach to the right stifle joint, arthrotomy was performed for menisci injury inspection and joint debridement. The caudal pole of the medial meniscus and fragments of the cranial cruciate ligament were removed. The joint capsule was sutured. The medial aspect of the tibia was meticulously marked for both TPLO and CCWO osteotomies using a monopolar electrocautery. The TPLO cut was performed using a $21 \mathrm{~mm}$ blade and the segment was rotated $7.9 \mathrm{~mm}$. Two $1.5 \mathrm{~mm}$ Kirschner wires were inserted craniocaudally in the tibia to stabilize the fragment. Then, the proximal cut of the CCWO was made perpendicularly to the tibial axis in the transverse plane, and the distal cut caudal to the TPLO, as it was planned before. Tibial fragments were also fixed temporarily with a $1.5 \mathrm{~mm}$ Kirschner wire.

Both osteotomies were fixed with a double plating technique. A $3.5 \mathrm{~mm}$ locking compression TPLO plate (Cão Médica®) was positioned on the medial aspect of the tibia, achieving interfragmentary compression. In addition, a 2.0 $\mathrm{mm}$ locking reconstruction plate (Focus ${ }^{\circledR}$ ) was implanted in the craniomedial region, providing 
stability of tibial fragments. Surgical wound was sutured as usual (Figure 3A). Postoperative radiographs showed a TPA of $12^{\circ}$ (Figure 3B), differing from the one planned at the beginning $\left(5^{0}\right)$. Due to small inaccuracies at the moments of measurements, CCWO osteotomies and TPLO rotation, it is possible that the final angle generated is above the planned, although this did not affect the expected final result. After surgery, the patient was recommended enrofloxacin (Baytril, enrofloxacin, Bayer, Brazil) $(5 \mathrm{mg} / \mathrm{kg}$ BID Orally) for 10 days, meloxicam (Maxicam, meloxicam, Ourofino, Brazil) $(0,1 \mathrm{mg} / \mathrm{kg}$ SID Orally) for 5 days and Tramadol hydrochloride (Tramal Retard, tramadol hydrochloride, Pfzer, Brazil) (4mg/kg TID VO) for 7 days. It was discharged with restricted activity and physiotherapy recommendation and monthly returns for orthopedic evaluations and radiographic control.

Postoperative radiographs and orthopedic evaluation were performed at 30, 60, 90, 120 and 150 day postoperatively. No lameness was observed on day 90. Radiographic consolidation occurred at 150 days postoperatively (Figure 3C), when the patient was discharged. Through telephone contact, at the time of this paper (3 years postoperatively), the owner reports no further complications.

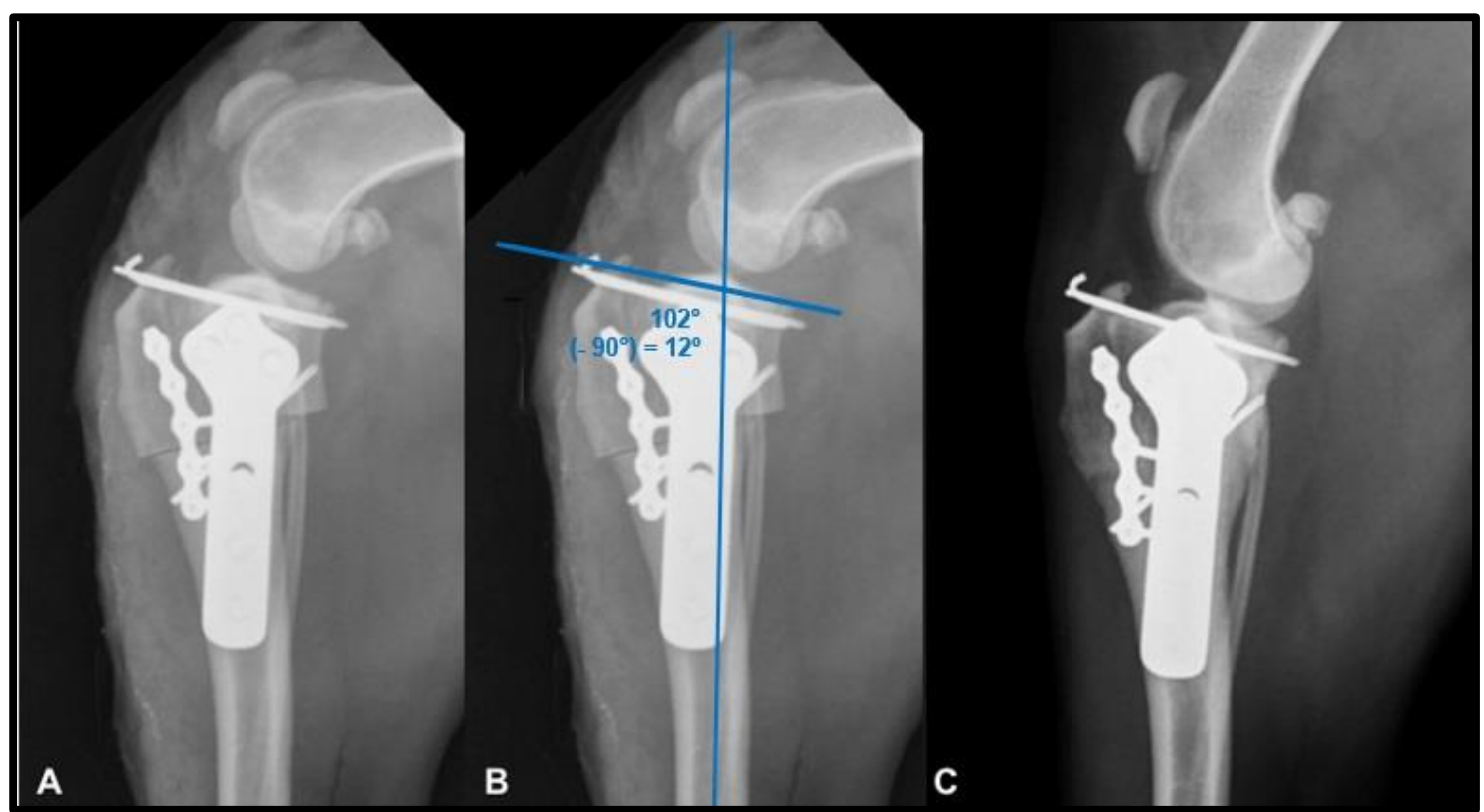

Figure 3. Lateral radiographs of the right stifle joint of male American pit bull dog after the surgery showing a double plating fixation of the TPLO and CCWO osteotomies (A). The tibial plateau angle of $12^{\circ}$ can be observed (B). Bone consolidation at 150 days postoperatively (C).

\section{DISCUSSION}

The combination of TPLO and CCWO has been reported for the treatment of patients presenting TPA greater than $36^{\circ}$, however, complication rates have been markedly high (Talaat et al., 2006). In this case report, in spite of an abnormal ambulation, mild genu valgum and external rotation during limb support, without identifiable deviations on radiographs, presented in the first 60 days of postoperative period, the patient presented normal limb function and bone consolidation at
150 days postoperatively, with no long-term major complications.

Considering that migration or implant failures were the major complications found in this association of techniques (Talaat et al., 2006; Duerr et al., 2008; Weh et al., 2011), we chose to replace the tension band by a double plating approach using an additional reconstruction locking plate. We believe that this modification of the technique previously described (Talaat et al., 2006) reduced the chance of complications. 
The second plate might help decreasing micromovement and preventing an overload of kirschner wires. However, controlled clinical trials with greater number of cases are required to confirm this hypothesis. As demonstrated in the present report, Wallace et al. (2011) also used a type of modified CCWO technique and compared their results with those of the standard technique. The main difference from the modified one used by them was the significantly smaller amount of bone removed, which facilitates the positioning of the implant, as it preserves greater bone stock and also reduces tibial shortening.

Although some studies have shown no correlation between TPA and cranial cruciate ligament disease (Reif and Probst, 2003; Buote et al., 2009), dogs with excessive tibial plateau angle may be predisposed to ligament rupture due to increased tibiofemoral shear forces (Read and Robins, 1982; Morris and Lipowitz, 2001; Macias et al., 2002). Our patient had an excessive tibial plateau angle probably due to the malunion after a conservative fracture treatment, since no changes were observed in the contralateral limb. It is believed that there has been a relationship between the $42^{\circ}$ TPA and the cruciate disease diagnosed in this dog. The TPA after surgery was $12^{\circ}$ which provided satisfactory clinical results after 90 days postoperatively. It is compatible with previous reports that also found acceptable clinical results in patients with postoperative TPA of up to $14^{\circ}$ (Talaat et al., 2006; Duerr et al., 2008).

Radiographic consolidation occurred after 150 days, while other authors reported a variation of 70 and 120 days (Talaat et al., 2006; Weh et al., 2011). The delayed consolidation may be due to the absence of compression in the CCWO fragments. The shorter time for consolidation observed by other authors suggests that tension band had successfully achieved interfragmentary compression.

\section{CONCLUSIONS}

There is no consensus on the best technique to be performed on patients with cranial cruciate disease and excessive tibial plateau angle. Although literature cites high rates of complication in the association of TPLO and CCWO, the modified technique applied in this case using a more robust fixation presented no complications that compromised the patient's recovery or that would require further surgical intervention. However, studies with a greater number of cases are necessary to evaluate the rates of complications associated with the modified technique.

\section{REFERENCES}

BERGH, M.S.; SULLIVAN, C.; FERRELL, C.L. et al. Systematic review of surgical treatments for cranial cruciate ligament disease in dogs. J. Am. Anim. Hosp. Assoc., v.50, p.315-321, 2014.

BUOTE, N.; FUSCO, J.; RADASCH, R. Age, tibial plateau angle, sex, and weight as risk factors for contralateral rupture of the cranial cruciate ligament in Labradors. Vet. Surg., v.38, p.481489, 2009.

DUEER, F.M.; DUNCAN, C.G.; SAVICK, R.S. et al. Comparison of surgical treatment options for cranial cruciate ligament disease in large-breed dogs with excessive tibial plateau angle. Vet. Surg., v.37, p.49-62, 2008.

KOWALESKI, M.P.; BOUDRIEAU, R.J.; POZZI, A. Stifle joint. In: TOBIAS, K.M.; JOHNSTON, S.A. Veterinary surgery: small animal. Canada: Saunders, 2012. p.906-998.

LIVET, V.; BALDINGER, A.; VIGUIER, É. et al. Comparison of outcomes associated with tibial plateau levelling osteotomy and a modified technique for tibial tuberosity advancement for the treatment of cranial cruciate ligament disease in dogs: a randomized clinical study. Vet. Comp. Orthop. Traumatol., v.32, p.314-323, 2019.

MACIAS, C.; MCKEE, W.M.; MAY, C. Caudal proximal tibial deformity and cranial cruciate ligament rupture in small breed dogs. J. Small Anim. Pract., v.43, p.433-438, 2002.

MORRIS, E.; LIPOWITZ, A.J. Comparison of tibial plateau angles in dogs with and without cranial cruciate ligament injuries. J. Am. Vet. Med. Assoc., v.218, p.363-366, 2001.

POWERS, M.Y.; MARTINEZ, S.A.; LINCOLN, J.D. et al. Prevalence of cranial cruciate ligament rupture in a population of dogs with lameness previously attributed to hip dysplasia: 369 cases. J. Am. Vet. Med. Assoc., v.227, p.1109-1111, 2005. 
READ, R. A.; ROBINS, G. M. Deformity of the proximal tibia in dogs. The Veterinary Record., v.111, p.295-298, 1982.

REIF, U.; PROBST, C.W. Comparison of tibial plateau angles in normal and cranial cruciate deficient stifles of Labrador retrievers. Vet. Surg., v.32, p.385-389, 2003.

TALAAT, M.B.; KOWALESKI, M.P.; BOUDRIEAU, R.J. Combination tibial plateau leveling osteotomy and cranial closing wedge osteotomy of the tibia for the treatment of cranial cruciate ligament-deficient stifles with excessive tibial plateau angle. Vet. Surg., v.35, p.729-739, 2006.
WALLACE, A.M.; ADDISON, E.S.; SMITH, B.A. et al. Modification of the cranial closing wedge ostectomy technique for the treatment of canine cruciate disease: Description and comparison with standard technique. Vet. Comp. Orthop. Traumatol., v.24, p.457-462, 2011.

WEH, J.L.; KOWALESKI, M.P.; BOUDRIEAU, R.J. Combination tibial plateau leveling osteotomy and transverse corrective osteotomy of the proximal tibia for the treatment of complex tibial deformities in 12 dogs. Vet. Surg., v.40, p.670-686, 2011. 